Article

\title{
Seroprevalence of Bartonella henselae and Bartonella quintana Infection and Impact of Related Risk Factors in People from Eastern Slovakia
}

\author{
Katarína Petríková ${ }^{1}$, Monika Halánová ${ }^{1, *(D)}$, Ingrid Babinská ${ }^{1} \mathbb{D}$, Mariia Logoida $^{1}$, Karin Kaliariková ${ }^{1}$, \\ Peter Jarčuška ${ }^{2}$, Sylvia Dražilová ${ }^{2} \mathbb{D}$, Vladimíra Sobolová ${ }^{3}$ and Martin Janičko ${ }^{2} \mathbb{D}$ \\ 1 Department of Epidemiology, Faculty of Medicine, Pavol Jozef Šafárik University in Košice, \\ 04011 Košice, Slovakia; katarina.petrikova@student.upjs.sk (K.P.); ingrid.babinska@upjs.sk (I.B.); \\ mariia.logoida@student.upjs.sk (M.L.); karin.kaliarikova@gmail.com (K.K.) \\ 2 2nd Department of Internal Medicine, Faculty of Medicine, Pavol Jozef Šafárik University, \\ 04011 Košice, Slovakia; peter.jarcuska@upjs.sk (P.J.); sylvia.drazilova@upjs.sk (S.D.); \\ martin.janicko@upjs.sk (M.J.) \\ 3 Department of Urology, Faculty of Medicine, Pavol Jozef Šafárik University, 04011 Košice, Slovakia; \\ vladimira.sobolova@student.upjs.sk \\ * Correspondence: monika.halanova@upjs.sk; Tel.: +421-55-234-3374
}

Citation: Petríková, K.; Halánová, M.; Babinská, I.; Logoida, M.; Kaliariková, K.; Jarčuška, P.; Dražilová, S.; Sobolová, V.; Janičko, M. Seroprevalence of Bartonella henselae and Bartonella quintana Infection and Impact of Related Risk Factors in People from Eastern Slovakia. Pathogens 2021, 10, 1261. https:// doi.org/10.3390/pathogens10101261

Academic Editor: Edward

B. Breitschwerdt

Received: 8 August 2021

Accepted: 27 September 2021

Published: 29 September 2021

Publisher's Note: MDPI stays neutral with regard to jurisdictional claims in published maps and institutional affiliations.

Copyright: (c) 2021 by the authors. Licensee MDPI, Basel, Switzerland. This article is an open access article distributed under the terms and conditions of the Creative Commons Attribution (CC BY) license (https:// creativecommons.org/licenses/by/ $4.0 /)$.
Abstract: The genus Bartonella is a rapidly expanding group of ubiquitous bacteria that occur mainly in different animal species, but some can also be transmitted to humans. Three species, B. henselae, B. bacilliformis, and B. quintana, are responsible for the majority of human cases. The severity of the clinical symptoms often depends on the immune status of the patient, but others factors such as the species of the pathogen, virulence factors, and bacterial load also can play an important role. As the information on the occurrence of bartonellosis in the human population in Slovakia is absent, the aim of our pilot study was to determine the seroprevalence against B. henselae and B. quintana in the population of people living in Eastern Slovakia, and to identify the impact of related risk factors. Of 536 people included in the study, 126 (23.5\%) showed positivity for anti-B. henselae antibodies and $133(24.8 \%)$ against B. quintana. A statistically higher prevalence was confirmed only in the case of $B$. quintana in women regardless of the risk group. In analyzing the risk factors, we found significant differences between $B$. henselae seropositive and seronegative groups only in uric acid levels and serum creatinine, both, however, clinically irrelevant. Significant, but clinically irrelevant differences were observed also in alanine aminotransferase (ALT) levels and creatinine in people seropositive to B. quintana.

Keywords: Bartonella henselae; Bartonella quintana; IgG antibodies; seroprevalence; risk factors; Slovakia

\section{Introduction}

Bartonella infections, belonging to a group of emerging diseases, are caused by a Gram-negative, aerobic, pleomorphic, intracellular pathogens of the order Rhizobiales, genus Bartonella.

Bartonellosis was first described in 1909, and by 1990 only two species of Bartonella were known. Since the last reclassification in 1993, the number of Bartonella species has increased to 45 [1].

Among all the Bartonella species, there are at least 16 species that have been associated with the human disease-Bartonella (B.) alsatica, B. ancashensis, B. bacilliformis, B. bovis, $B$. clarridgeiae, B. doshiae, B. elizabethae, B. grahamii, B. henselae, B. koehlerae, B. mayotimonensis, B. quintana, B. rochalimae, B. tamiae, B. vinsonii subsp. arupensis and B. vinsonii subsp. berkhoffi [1-3]. With the exception of B. bacilliformis, which has a human reservoir, other species are zoonotic. Multiple reservoirs for the development of human Bartonella infec- 
tions are both domestic and wild animals. In Europe, these are mainly cats, dogs, and rodents $[4,5]$.

Three species-B. henselae, B. bacilliformis, and B. quintana-are mainly responsible for most human Bartonella diseases.

$B$. henselae is the etiological agent of one of the most well-known zoonotic human infections caused by Bartonella — cat scratch disease (CSD) [6]. Carrion's disease, endemic to South American Andean valleys, is caused by the B. bacilliformis [7], and B. quintana is the causative agent of Trench fever [8].

Diseases caused by these microorganisms are mainly transmitted by the bite or scratch of infected animals or by different insect vectors, while some arthropods were proved as a vector of Bartonella infections (e.g., fleas, flies, lice) and some are suspected to be involved in transmission (e.g., some species of bed bugs, ticks, red ants, spiders), depending on the bacteria species and their vertebrate reservoirs [1,2,9-14]. Increased interest in Bartonella became evident only in the early 1990s, when B. quintana and B. henselae were first described in HIV-infected patients and subsequently in immunocompetent persons [15]. Infections caused by these pathogens are responsible for a variety of manifestations from asymptomatic or mild symptoms, such as low-grade fever, malaise, regional lymphadenopathy, and headache, to more severe symptoms, such as endocarditis, meningitis, osteomyelitis, hemolytic anemia, hepatosplenomegaly, glomerulonephritis, and encephalitis $[1,16]$. The severity of clinical symptoms often depends on the immune status of the patient, but others factors such as the species of the pathogen, virulence factors, and bacterial load also can play an important role [3].

The prevalence of Bartonella spp. varies among different geographic regions, groups of examined people, and the diagnostic method used [17]. Most of the results were obtained through serological surveys to estimate the incidence of human bartonellosis [3].

As there is no law in Slovakia that imposes systematic screening for this infection, information on the occurrence of this disease in humans are absent. Thus far, this infection has been confirmed in Slovakia only in small mammals, with positivity ranging between $9 \%$ and $73.8 \%[18,19]$.

Risk factors associated with Bartonella infections include direct contact with infected animals (especially with stray cats and rodents). A variety of insects, including fleas, body lice, and ticks, act as vectors and play an important role in transmission not only between animals but also between animals and humans [2,10]. Their occurrence is most commonly associated with homelessness or areas of high population density and poor sanitation [20]. For these reasons, unsatisfactory social conditions and insufficient medical care are also described as potential risk factors. Therefore, the aim of our study was to determine the prevalence of antibodies against $B$. henselae and B. quintana in the population of people living in Eastern Slovakia and to identify the impact of related risk factors.

\section{Results}

\subsection{Baseline}

Analysis of baseline information of the people living in segregated Roma settlements (risk group) and people from the general population showed that this two populations are completely different in terms of demographics, socioeconomic status, and biochemical parameters (except transaminases), (Table 1).

\subsection{Antibodies Prevalence}

In the case of a positive immunological response to the presence $\operatorname{IgG}$ antibodies against B. henselae and B. quintana, an apple-green fluorescence was detected. Samples that showed fluorescence at titers of 1:64 and above were considered positive. 
Table 1. Baseline differences between Roma $(n=283)$ and non-Roma $(n=253)$ population in Eastern Slovakia.

\begin{tabular}{|c|c|c|c|}
\hline Parameter & Roma n (\%) & Non-Roma n (\%) & $p$ Value \\
\hline \multicolumn{4}{|c|}{ demographic variables } \\
\hline Age, mean (STD) & $35.1(0.6)$ & $32.6(0.5)$ & 0.001 \\
\hline Male gender & $93(32.9)$ & $119(47)$ & 0.001 \\
\hline \multicolumn{4}{|c|}{ socioeconomic variables } \\
\hline Basic education & $228(82.6)$ & $3(1.2)$ & \multirow{3}{*}{$<0.0001$} \\
\hline Intermediate education & $48(17.4)$ & $150(61)$ & \\
\hline Higher education & $0(0)$ & $93(37.8)$ & \\
\hline Unemployment & $250(90.9)$ & $62(25.7)$ & $<0.0001$ \\
\hline Poverty & $134(47.3)$ & $20(7.9)$ & $<0.0001$ \\
\hline Bricked house & $265(95.3)$ & $231(100)$ & $<0.0001$ \\
\hline Missing household equipment & $188(66.4)$ & $45(17.8)$ & $<0.0001$ \\
\hline $\begin{array}{l}\text { Number of persons in house, mean } \\
\text { (STD) }\end{array}$ & $7.5(0.2)$ & $4.3(0.3)$ & $<0.0001$ \\
\hline No preventive medical check-up & $146(52.5)$ & $82(33.7)$ & $<0.0001$ \\
\hline \multicolumn{4}{|c|}{ laboratory variables } \\
\hline AST (ukat/L) & $0.31 \pm 0.03$ & $0.32 \pm 0.01$ & 0.673 \\
\hline ALT (ukat/L) & $0.24 \pm 0.24$ & $0.25 \pm 0.01$ & 0.629 \\
\hline Uric Acid (umol/L) & $223.3 \pm 4.9$ & $253.8 \pm 5.6$ & $<0.0001$ \\
\hline Albumin (g/L) & $46.6 \pm 0.2$ & $47.2 \pm 0.2$ & 0.026 \\
\hline Creatinine (umol/L) & $82.1 \pm 0.7$ & $85.4 \pm 0.8$ & 0.001 \\
\hline CRP (mg/L) & $3.1 \pm 0.24$ & $1.99 \pm 0.18$ & $<0.0001$ \\
\hline
\end{tabular}

Of the 536 respondents included in the study, 126 (overall prevalence $23.5 \%, 95 \%$ CI 20.0-27.1) showed positivity for IgG antibodies against B. henselae. In the case of $B$. quintana, IgG antibodies were confirmed in 133 people and overall prevalence was $24.8 \%$ (95\% CI 21.3-28.7). Basic differentiation of seroprevalence based on gender and risk group is presented in Table 2 . We observed no statistically significant difference in any antibody prevalence between Roma (risk group) and non-Roma participants. Irrespective of risk group, women had statistically higher prevalence of B. quintana IgG positivity and no difference was observed in $B$. henselae IgG seropositivity in regards to gender or risk group.

Table 2. Prevalence of anti-B. henselae and anti-B. quintana IgG based on risk group and gender.

\begin{tabular}{cccccc}
\hline & \multicolumn{2}{c}{ Roma } & \multicolumn{2}{c}{ Non-Roma } & p Value \\
\cline { 2 - 5 } & Male n (\%) & Female n (\%) & Male n (\%) & Female n (\%) & \\
\hline $\begin{array}{c}\text { B. henselae } \\
\text { IgG }\end{array}$ & $21(22.6)$ & $46(24.2)$ & $20(16.8)$ & $39(29.1)$ & 0.145 \\
\hline $\begin{array}{c}\text { B. quintana } \\
\text { IgG }\end{array}$ & $21(22.6)$ & $59(31.1)$ & $14(11.8)$ & $39(29.1)$ & 0.001 \\
\hline
\end{tabular}

\subsection{Risk Factors for Antibodies Prevalence}

Because of no significant difference in any antibody prevalence between Roma and non-Roma, differences in potential risk factors were analyzed in the whole cohort (Table 3). 
Table 3. Differences in potential risk factors between seropositive and seronegative patients.

\begin{tabular}{|c|c|c|c|c|c|c|}
\hline \multirow{2}{*}{ Parameter } & \multicolumn{2}{|c|}{ Anti-B. henselae IgG } & \multirow{2}{*}{$p$ Value } & \multicolumn{2}{|c|}{ Anti-B. quintana IgG } & \multirow{2}{*}{$p$ Value } \\
\hline & Positive n (\%) & Negative n (\%) & & Positive n (\%) & Negative $n(\%)$ & \\
\hline \multicolumn{7}{|l|}{ Demographic variables } \\
\hline Age, mean (STD) & $34.5 \pm 7$ & $33.8 \pm 0.4$ & 0.418 & $34.7 \pm 0.8$ & $33.7 \pm 0.4$ & 0.200 \\
\hline Male gender & $41(32.5)$ & $171(41.7)$ & 0.076 & $35(26.3)$ & $177(43.9)$ & $<0.0001$ \\
\hline \multicolumn{7}{|l|}{ Socioeconomic variables } \\
\hline Basic education & $54(44.3)$ & $177(44.3)$ & \multirow{3}{*}{0.997} & $72(55.4)$ & $159(40.6)$ & \multirow{3}{*}{0.012} \\
\hline Intermediate education & $46(37.7)$ & $152(38.0)$ & & $41(31.5)$ & $157(40.1)$ & \\
\hline Higher education & $22(18)$ & $71(17.8)$ & & $17(13.1)$ & $76(19.4)$ & \\
\hline Unemployment & $71(57.7)$ & $241(61.3)$ & 0.526 & $85(64.9)$ & $227(59)$ & 0.256 \\
\hline Poverty & $43(34.1)$ & $111(27.1)$ & 0.143 & $40(30.1)$ & $114(28.3)$ & 0.740 \\
\hline Bricked house & $115(98.3)$ & $381(97.2)$ & 0.742 & $125(98.4)$ & $371(97.1)$ & 0.533 \\
\hline $\begin{array}{l}\text { Missing household } \\
\text { equipment }\end{array}$ & $58(46)$ & $175(42.7)$ & 0.538 & $65(48.9)$ & $168(41.7)$ & 0.159 \\
\hline $\begin{array}{l}\text { Number of persons in } \\
\text { house, mean (STD) }\end{array}$ & $5.9 \pm 0.3$ & $6.2 \pm 0.25$ & 0.517 & $6.42 \pm 0.3$ & $6.04 \pm 0.3$ & 0.421 \\
\hline $\begin{array}{l}\text { No preventive medical } \\
\text { check-up }\end{array}$ & $51(42.1)$ & $177(44.3)$ & 0.754 & $51(38.9)$ & $177(45.4)$ & 0.222 \\
\hline \multicolumn{7}{|l|}{ Laboratory variables } \\
\hline AST (ukat/L) & $0.28 \pm 0.01$ & $0.33 \pm 0.02$ & 0.153 & $0.27 \pm 0.01$ & $0.33 \pm 0.02$ & 0.069 \\
\hline ALT (ukat/L) & $0.21 \pm 0.01$ & $0.26 \pm 0.02$ & 0.115 & $0.19 \pm 0.01$ & $0.26 \pm 0.02$ & 0.002 \\
\hline Uric Acid (umol/L) & $223.23 \pm 7.5$ & $242.25 \pm 4.3$ & 0.028 & $227.01 \pm 6.8$ & $241.32 \pm 4.4$ & 0.078 \\
\hline Albumin $(\mathrm{g} / \mathrm{L})$ & $46.62 \pm 0.3$ & $46.97 \pm 0.1$ & 0.254 & $46.62 \pm 0.2$ & $46.97 \pm 0.2$ & 0.230 \\
\hline Creatinine (umol/L) & $81.05 \pm 0.9$ & $84.45 \pm 0.6$ & 0.002 & $81.25 \pm 0.8$ & $84.45 \pm 0.6$ & 0.002 \\
\hline CRP (mg/L) & $2.42 \pm 0.3$ & $2.64 \pm 0.18$ & 0.556 & $2.70 \pm 0.37$ & $2.55 \pm 0.17$ & 0.698 \\
\hline
\end{tabular}

Roma ethnicity was entered as a confounding factor, along with gender in the multivariate regression model (Table 4). After adjustment for ethnicity and gender only, serum creatinine was marginally inversely associated with $B$. henselae seropositivity, but with low OR. Analogous analysis with $B$. quintana showed strong association with female gender (OR 2.1) and weaker association with basic education. All other analyzed risk factors were insignificant.

Table 4. Adjusted risk for B. henselae and B. quintana seropositivity.

\begin{tabular}{ccccc}
\hline Parameter & $\begin{array}{c}\text { OR for Anti-B. } \\
\text { henselae IgG } \\
\text { Positivity }\end{array}$ & $p$ Value & $\begin{array}{c}\text { OR for Anti-B. } \\
\text { quintana IgG } \\
\text { Positivity }\end{array}$ & $p$ Value \\
\hline demographic variables & 0.712 & $1.009(0.986-1.034)$ & 0.442 \\
\hline Age & $1.009(0.984-1.033)$ & 0.066 & $0.476(0.307-0.736)$ & 0.001 \\
\hline Male gender & $0.671(0.438-1.027)$ & 0.863 & $0.738(0.492-1.107)$ & 0.142 \\
\hline
\end{tabular}


Table 4. Cont.

\begin{tabular}{|c|c|c|c|c|}
\hline Parameter & $\begin{array}{l}\text { OR for Anti-B. } \\
\text { henselae IgG } \\
\text { Positivity }\end{array}$ & $p$ Value & $\begin{array}{l}\text { OR for Anti-B. } \\
\text { quintana IgG } \\
\text { Positivity }\end{array}$ & $p$ Value \\
\hline \multicolumn{5}{|c|}{ socioeconomic variables } \\
\hline Basic education & $0.984(0.385-2.512)$ & 0.972 & $3.031(1.092-8.413)$ & 0.033 \\
\hline Intermediate education & $0.988(0.537-1.816)$ & 0.968 & $1.297(0.674-2.495)$ & 0.437 \\
\hline Higher education & Reference & & Reference & \\
\hline Unemployment & $0.743(0.422-1.307)$ & 0.302 & $0.845(0.477-1.496)$ & 0.563 \\
\hline Poverty & $1.53(0.944-2.481)$ & 0.084 & $0.922(0.572-1.485)$ & 0.738 \\
\hline Bricked house & $1.922(0.413-8.944)$ & 0.405 & $2.751(0.592-12.781)$ & 0.197 \\
\hline Missing household equipment & $1.157(0.727-1.842)$ & 0.539 & $1.090(0.690-1.724)$ & 0.712 \\
\hline Number of persons in house & $0.981(0.927-1.038)$ & 0.507 & $1.0(0.951-1.052)$ & 0.998 \\
\hline $\begin{array}{c}\text { No preventive medical } \\
\text { check-up }\end{array}$ & $0.907(0.596-1.381)$ & 0.651 & $0.680(0.447-1.034)$ & 0.072 \\
\hline \multicolumn{5}{|c|}{ laboratory variables } \\
\hline AST & $0.377(0.066-2.150)$ & 0.272 & $0.276(0.035-2.193)$ & 0.223 \\
\hline ALT & $0.443(0.121-1.623)$ & 0.219 & $0.362(0.086-1.517)$ & 0.165 \\
\hline Uric Acid & $0.998(0.995-1.001)$ & 0.124 & $1(0.997-1.003)$ & 0.894 \\
\hline Albumin & $0.974(0.907-1.046)$ & 0.474 & $0.992(0.926-1.063)$ & 0.815 \\
\hline Creatinine & $0.971(0.947-0.996)$ & 0.021 & $0.993(0.970-1.017)$ & 0.566 \\
\hline CRP & $0.981(0.925-1.041)$ & 0.537 & $1.003(0.950-1.059)$ & 0.916 \\
\hline
\end{tabular}

\section{Discussion}

Several new species and subspecies of the genus Bartonella have been characterized since the beginning of the 1990s. As a result, the spectrum of natural reservoirs, vectors, and subsequent human diseases caused by these species has expanded considerably [17].

In our study, we focused on the investigation of the prevalence of anti-B. henselae and anti-B. quintana antibodies in people living in Eastern Slovakia and identification of risk factors that may be involved in the development of the disease.

In the case of $B$. henselae, the most prevalent zoonotic Bartonella species occurring endemically worldwide, cats are the primary reservoir, but DNA from this pathogen has also been found in dogs, cows, horses, marine mammals, and sea turtles [3,21-23]. Infected cats usually have asymptomatic bacteremia lasting several months [3]. Transmission to humans occurs directly through a skin injury after a cat scratching or biting and may occur after being bitten by cat fleas (Ctenocephalides felis) also [3,24]. Other vectors, such as ticks, mites, and spiders are also an equivalent vectors for $B$. henselae and can play an important role in their transmission to humans and animals $[3,25]$.

B. quintana has a worldwide distribution often associated with war zones and poor hygiene, which is related to the predisposition to contamination of the human body louse (Pediculus humanus humanus) [26,27]. This bacteria is an etiological agent of Trench fever and is also one of the pathogens of bacillary angiomatosis occurring in immunodeficient patients [28]. In addition, it may be involved in endocarditis and chronic bacteremia in people living in poor conditions (e.g., in homeless people), and is referred to as "urban trench fever" [29]. DNA of B. quintana has been isolated from feline fleas and ticks, and this bacteria has been confirmed in dogs, in addition to feral cats [30-32].

Generally, Bartonella infection in humans can be difficult to diagnose. Culture, molecular, and serological tests can be used, but since the causative agent cannot be easily cultured, the diagnosis usually relies on epidemiological, clinical, and serological proof. 
In Slovakia, to date, bartonellosis in humans has not been officially reported. As is known from foreign studies, the occurrence of many Bartonella species is often associated with poor hygiene, unfavorable social conditions, and a low standard of living. In Slovakia, these conditions mainly concern people living in segregated Roma settlements. There is generally a higher prevalence of infectious diseases, poisoning, and injuries in this group [33]. These places are also characterized by a huge number of stray animals (especially dogs, cats, and rodents), which may have a direct share in their incidence.

Although our study confirmed that Roma live in socially weaker conditions compared to the majority (Table 1), and it could be expected that the incidence of Bartonella infections would be higher in the Roma population due to poor hygienic standards and increased contact with stray animals as a risk factor, our study did not confirm this. A statistically higher prevalence was confirmed only in the case of B. quintana in women regardless of the risk group. The explanation might be that having high hygienic standards in an area where other community could not afford it and where stray animals (especially stray cats) are increasingly present without proper management of risk does not prevent Bartonella infections efficiently.

In analyzing the risk factors, we found significant differences between $B$. henselae seropositive and seronegative groups only in uric acid levels and serum creatinine, both, however, clinically irrelevant. Significant, but clinically irrelevant differences were observed also in ALT levels and creatinine in people seropositive to B. quintana.

The overall seropositivity ( $23.5 \%$ for B. henselae and $24.8 \%$ for B. quintana) we found is comparable to the results of other studies. Generally, the prevalence of Bartonella infections in humans varies from $0.2 \%$ to $30 \%$ on average, depending on the investigated group and the diagnostic method used. For example, in a study conducted in Germany, the seropositivity rates among the healthy adults are $30 \%$, in Greece $19.8 \%$, in Poland $25.85 \%$, in Austria 26.5\%, in Sweden 16\%, and 8.7\% in Spain [25,34-36]. On the other hand, bartonellosis in Slovakia is not subject to mandatory reporting and, therefore, it is not possible to accurately determine incidence and prevalence. Because of the different results between studies and the overall lack of microbiological data in clinical and therapeutic studies, many problems have been encountered in diagnosis and subsequent therapy not only in humans but also in infected animals. Therefore, there is a need to further investigate Bartonella infections in the population and to study associations of the occurrence of Bartonella antibodies in humans and animals.

However, our study also has some limitations. First, the respondents were not asked directly about arthropod exposure or animal scratch, and we only hypothesize that it might happen, as it is quite common. However, the relevant exposure period is quite long and many respondents might not remember the accident, so it is questionable how reliable the retrospective data on it would be.

Another limitation may be the diagnostic test used. In our study, detection of IgG antibodies to Bartonella infections was done using a commercial indirect immunofluorescent assay (IFA) kit. This test uses Vero cells that have been infected with either $B$. henselae or B. quintana as the individual substrates permitting the qualitative detection and semiquantitation of human serum IgG antibodies to Bartonella. This test uses only a small blood sample for reliable diagnosis; however, cross-reactive between species may occur and, therefore, the results should be interpreted with caution.

\section{Materials and Methods}

\subsection{Study Population}

Samples and data from the cross-sectional population-based Hepa-Meta study conducted in Eastern Slovakia were used. The study focused on the prevalence of viral hepatitis diseases, metabolic syndrome, and selected bacterial and parasitic infectious diseases in the population living in segregated settlements. The inhabitants from the general population from the same region were used as a control group. The methodology of this study was previously described in detail by Madarasová Gecková et al. [37]. 
The final sample that examined the presence of IgG antibodies against $B$. henselae and $B$. quintana was comprised of 536 people aged 18-55, randomly selected from the overall HepaMeta database $(n=855)$. The study cohort consisted of 283 people living in 10 different segregated Roma settlements in Eastern Slovakia (mean age $=35.08 ; \mathrm{SD}=9.28 ; 32.9 \%$ men) and 253 people from the general population from the same region (mean age $=32.61$; $\mathrm{SD}=7.23 ; 47 \%$ men) who were used as a control group.

Data were collected via analyzed blood and a questionnaire. Venous blood was collected from vena mediana cubiti under standard conditions. After centrifugation of the blood, serum samples were collected and stored at $-80{ }^{\circ} \mathrm{C}$ until their use in the immunofluorescence test. Hyperlipemic, hemolyzed, and contaminated sera were excluded from testing.

The questionnaire gathered information about the sociodemographic background (employment status, education), living conditions (type of house, the number of people per house, availability of in-house sanitary equipment, electricity supply), and poverty (aggregate of the issue to pay at least one item of the following: rent, loan payment, healthcare, energies, other expenses).

\subsection{Laboratory Examination}

Detection of IgG antibodies to Bartonella infections was done using a commercial indirect immunofluorescent assay (IFA) kit (Focus Diagnostics, Cypress, CA, USA).

A kit that uses Vero cells infected with either B. henselae or B. quintana for detecting IgG antibodies was used according to the manufacturer's instructions.

Antibody determination was performed in two phases. In the first step, the blood sera were diluted at a 1:64 screening dilution and then added to appropriate slide wells containing B. henselae and B. quintana antigens. After incubation for $60 \mathrm{~min}$ at room temperature and then washing, the fluorescently labelled anti-IgG antibodies were added to the wells. Afterwards, the slide was washed, dried and mounted and was examined using fluorescence microscopy at $400 \times$ magnification.

Biochemical parameters-aspartate aminotransferase (AST), alanine aminotransferase (ALT), uric acid, albumin, creatinine, and C-reactive protein (CRP) were determined by routine biochemical methods on the analyzer ADVIA 2400. Reference values for men were for AST 0.17-0.85 ukal/L, ALT 0.3-0.8 ukat/L, uric acid 220-420 ukat/L, albumin 32-48 g/L, creatinine 66-106 umol/L, and CRP 0-5 mg/L. For women the reference values were for AST 0.17-0.6 ukal/L, ALT 0.2-0.7 ukat/L, uric acid 140-340 ukat/L, albumin 32-48 g/L, creatinine 44-84 umol/L, and CRP 0-5 mg/L.

\subsection{Statistical Analyses}

Categorical variables are reported as absolute and relative frequency (n (\%)). Interval variables are reported as mean \pm standard error of mean. Baseline comparisons of the prevalence between groups based on various demographic, socio-economic, and laboratory variables were performed by Chi-squared test in case of categorical variables or Mann-Whitney test in case of interval variables. Adjusted odds ratios of variables that significantly differed between positive and negative groups were obtained by multivariate logistic regression adjusted for confounders. Two-sided $p$ value $<0.05$ was considered statistically significant.

Author Contributions: Conceptualization, M.H. and K.P.; methodology, M.H., K.P. and I.B.; software, I.B. and M.J.; validation, M.H., S.D., P.J. and M.J.; formal analysis, M.H., K.P., I.B., M.L., K.K. and V.S.; investigation, K.P., M.L. and K.K.; writing-original draft preparation, K.P., M.H., I.B. and M.J.; writing-review and editing, M.H., P.J. and S.D.; supervision, M.H.; project administration, M.H.; funding acquisition, M.H. All authors have read and agreed to the published version of the manuscript.

Funding: This research was funded by the Slovak Grant Committee VEGA, project No. 1/0084/18. 
Institutional Review Board Statement: The study was conducted according to the guidelines of the Declaration of Helsinki, and approved by the by the Ethics Committee of the Faculty of Medicine at P. J. Šafárik University in Košice (No. 104/2011).

Informed Consent Statement: Participation in the study was fully voluntary and anonymous, and written informed consent was obtained from all subjects involved in the study prior to the medical examination.

Data Availability Statement: The data presented in this study are available on request from the corresponding author.

Conflicts of Interest: The authors declare no conflict of interest.

\section{References}

1. Okaro, U.; Addisu, A.; Casanas, B.; Anderson, B. Bartonella Species, an Emerging Cause of Blood-Culture-Negative Endocarditis. Clin. Microbiol. Rev. 2017, 30, 709-746. [CrossRef]

2. Breitschwerdt, E.B. Bartonellosis, one health and all creatures great and small. Vet. Dermatol. 2017, 8, 111-121. [CrossRef]

3. Cheslock, M.A.; Embers, M.E. Human Bartonellosis: An Underappreciated Public Health Problem? Trop. Med. Infect. Dis. 2019, 4, 69. [CrossRef]

4. Chomel, B.B.; Boulouis, H.J.; Maruyama, S.; Breitschwerdt, E.B. Bartonella spp. in pets and effect on human health. Emerg. Infect. Dis. 2006, 12, 389-394. [CrossRef] [PubMed]

5. Gundi, V.A.; Davoust, B.; Khamis, A.; Boni, M.; Raoult, D.; La Scola, B. Isolation of Bartonella rattimassiliensis sp. nov. and Bartonella phoceensis sp. nov. from European Rattus norvegicus. J. Clin. Microbiol. 2004, 42, 3816-3818. [CrossRef] [PubMed]

6. Regnery, R.L.; Anderson, B.E.; Clarridge, J.E., III; Rodriquez-Barradas, M.; Jones, D.C.; Carr, J.H. Characterization of a novel Rochalimaea species, $R$. henselae sp. nov., isolated from blood of a febrile, human immunodeficiency virus-positive patient. J. Clin. Microbiol. 1992, 30, 265-274. [CrossRef] [PubMed]

7. Garcia-Quintanilla, M.; Dichter, A.A.; Guerra, H.; Kempf, V.A.J. Carrion's disease: More than a neglected disease. Parasit. Vectors 2019, 12, 141. [CrossRef] [PubMed]

8. Kostrzewski, J. The epidemiology of Trench fever. Bull. Acad. Pol. Sci. (Med.) 1949, 7, 233-263.

9. Chomel, B.B.; Boulouis, H.J.; Breitschwerdt, E.B.; Kasten, R.W.; Vayssier-Taussat, M.; Birtles, R.J.; Koehler, J.E.; Dehio, C. Ecological fitness and strategies of adaptation of Bartonella species to their hosts and vectors. Vet. Res. 2009, 40, 29. [CrossRef] [PubMed]

10. Billeter, S.A.; Levy, M.G.; Chomel, B.B.; Breitschwerdt, E.B. Vector transmission of Bartonella species with emphasis on the potential for tick transmission. Med. Vet. Entomol. 2008, 22, 1-15. [CrossRef] [PubMed]

11. Mosbacher, M.E.; Klotz, S.; Klotz, J.; Pinnas, J.L. Bartonella henselae and the potential for arthropod vector-borne transmission. Vector-Borne Zoonotic. Dis. 2011, 11, 471-477. [CrossRef]

12. Guru, P.K.; Agarwal, A.; Fritz, A. A miraculous recovery: Bartonella henselae infection following a red ant bite. BMJ Case Rep. 2018, 2018. [CrossRef]

13. Mascarelli, P.E.; Maggi, R.G.; Hopkins, S.; Mozayeni, B.R.; Trull, C.L.; Bradley, J.M.; Hegarty, B.C.; Breitschwerdt, E.B. Bartonella henselae infection in a family experiencing neurological and neurocognitive abnormalities after woodlouse hunter spider bites. Parasit. Vectors 2013, 6, 98. [CrossRef]

14. Leulmi, H.; Bitam, I.; Berenger, J.M.; Lepidi, H.; Rolain, J.M.; Almeras, L.; Raoult, D.; Parola, P. Competence of Cimex lectularius bed bugs for the transmission of Bartonella quintana, the agent of Trench fever. PLoS Negl. Trop. Dis. 2015, 9, e0003789, Erratum in 2015, 9, e0003871. [CrossRef]

15. Welch, D.F.; Pickett, D.A.; Slater, L.N.; Steigerwalt, A.G.; Brenner, D.J. Rochalimaea henselae sp. nov., a cause of septicemia, bacillary angiomatosis, and parenchymal bacillary peliosis. J. Clin. Microbiol. 1992, 30, 275-280. [CrossRef] [PubMed]

16. Boulouis, H.J.; Chang, C.C.; Henn, J.B.; Kasten, R.W.; Chomel, B.B. Factors associated with the rapid emergence of zoonotic Bartonella infections. Vet. Res. 2005, 36, 383-410. [CrossRef]

17. Oteo, J.A.; Maggi, R.; Portillo, A.; Bradley, J.; García-Álvarez, L.; San-Martín, M.; Roura, X.; Breitschwerdt, E. Prevalence of Bartonella spp. by culture, PCR and serology, in veterinary personnel from Spain. Parasit. Vectors 2017, 10, 553. [CrossRef]

18. Špitálska, E.; Minichová, L.; Kocianová, E.; Škultéty, L’; Mahríková, L.; Hamšíková, Z.; Slovák, M.; Kazimírová, M. Diversity and prevalence of Bartonella species in small mammals from Slovakia, Central Europe. Parasitol. Res. 2017, 116, 3087-3095. [CrossRef]

19. Kraljik, J.; Paziewska-Harris, A.; Miklisová, D.; Blaňarová, L.; Mošanský, L.; Bona, M.; Stanko, M. Genetic diversity of Bartonella genotypes found in the striped field mouse (Apodemus agrarius) in Central Europe. Parasitology 2016, 143, 1437-1442. [CrossRef] [PubMed]

20. Patel, S.; Richert, M.E.; White, R.; Lambing, T.; Saleeb, P. A Case of Bartonella quintana Culture-Negative Endocarditis. Am. J. Case Rep. 2019, 20, 602-606. [CrossRef]

21. Breitschwerdt, E.B.; Maggi, R.G.; Chomel, B.B.; Lappin, M.R. Bartonellosis: An emerging infectious disease of zoonotic importance to animals and human beings. J. Vet. Emerg. Crit. Care 2010, 20, 8-30. [CrossRef] [PubMed]

22. Jones, S.L.; Maggi, R.; Shuler, J.; Alward, A.; Breitschwerdt, E.B. Detection of Bartonella henselae in the blood of 2 adult horses. J. Vet. Intern. Med. 2008, 22, 495-498. [CrossRef] [PubMed] 
23. Valentine, K.H.; Harms, C.A.; Cadenas, M.B.; Birkenheuer, A.H.; Marr, H.S.; Braun-McNeill, J.; Maggi, R.G.; Breitschwerdt, E.B. Bartonella DNA in loggerhead sea turtles. Emerg. Infect. Dis. 2007, 13, 949-950. [CrossRef] [PubMed]

24. Abbott, R.C.; Chomel, B.B.; Kasten, R.W.; Floyd-Hawkins, K.A.; Kikuchi, Y.; Koehler, J.E.; Pedersen, N.C. Experimental and natural infection with Bartonella henselae in domestic cats. Comp. Immunol. Microbiol. Infect. Dis. 1997, 20, 41-51. [CrossRef]

25. Müller, A.; Reiter, M.; Schötta, A.M.; Stockinger, H.; Stanek, G. Detection of Bartonella spp. in Ixodes ricinus ticks and Bartonella seroprevalence in human populations. Ticks Tick Borne Dis. 2016, 7, 763-767. [CrossRef] [PubMed]

26. Seki, N.; Sasaki, T.; Sawabe, K.; Sasaki, T.; Matsuoka, M.; Arakawa, Y.; Marui, E.; Kobayashi, M. Epidemiological studies on Bartonella quintana infections among homeless people in Tokyo, Japan. Jpn. J. Infect. Dis. 2006, 59, 31-35.

27. Brouqui, P. Arthropod-borne diseases associated with political and social disorder. Annu. Rev. Entomol. 2011, 56, 357-374. [CrossRef]

28. Koehler, J.E.; Tappero, J.W. Bacillary angiomatosis and bacillary peliosis in patients infected with human immunodeficiency virus. Clin. Infect. Dis. 1993, 17, 612-624. [CrossRef]

29. Brouqui, P.; Lascola, B.; Roux, V.; Raoult, D. Chronic Bartonella quintana bacteremia in homeless patients. N. Engl. J. Med. 1999, 340, 184-189. [CrossRef]

30. Rolain, J.M.; Franc, M.; Davoust, B.; Raoult, D. Molecular detection of Bartonella quintana, B. koehlerae, B. henselae, B. clarridgeiae, Rickettsia felis, and Wolbachia pipientis in cat fleas, France. Emerg. Infect. Dis. 2003, 9, 339-342. [CrossRef]

31. Breitschwerdt, E.B.; Maggi, R.G.; Duncan, A.W.; Nicholson, W.L.; Hegarty, B.C.; Woods, C.W. Bartonella species in blood of immunocompetent persons with animal and arthropod contact. Emerg. Infect. Dis. 2007, 13, 938-941. [CrossRef] [PubMed]

32. Kelly, P.; Rolain, J.M.; Maggi, R.; Sontakke, S.; Keene, B.; Hunter, S.; Lepidi, H.; Breitschwerdt, K.T.; Breitschwerdt, E.B. Bartonella quintana endocarditis in dogs. Emerg. Infect. Dis. 2006, 12, 1869-1872. [CrossRef] [PubMed]

33. Halánová, M.; Veseliny, E.; Kalinová, Z.; Jarčuška, P.; Janičko, M.; Urbančíková, I.; Pella, D.; Dražilová, S.; Babinská, I.; HepaMeta Team. Seroprevalence of Hepatitis E Virus in Roma Settlements: A Comparison with the General Population in Slovakia. Int. J. Environ. Res. Public Health 2018, 15, 904. [CrossRef] [PubMed]

34. Łysakowska, M.E.; Brzezińska, O.; Szybka, M.; Konieczka, M.; Moskwa, S.; Brauncajs, M.; Makowska, J.; Pastuszak-Lewandoska, D.; Grzegorczyk, J. The seroprevalence of Bartonella spp. in the blood of patients with musculoskeletal complaints and blood donors, Poland: A pilot study. Clin. Rheumatol. 2019, 38, 2691-2698. [CrossRef]

35. McGill, S.; Wesslén, L.; Hjelm, E.; Holmberg, M.; Auvinen, M.K.; Berggren, K.; Grandin-Jarl, B.; Johnson, U.; Wikström, S.; Friman, G. Bartonella spp. seroprevalence in healthy Swedish blood donors. Scand. J. Infect. Dis. 2005, 37, 723-730. [CrossRef]

36. Pons, I.; Sanfeliu, I.; Cardeñosa, N.; Nogueras, M.M.; Font, B.; Segura, F. Serological evidence of Bartonella henselae infection in healthy people in Catalonia, Spain. Epidemiol. Infect. 2008, 136, 1712-1716. [CrossRef]

37. Gecková, A.M.; Babinská, I.; Bobáková, D.; Veselská, Z.D.; Bosáková, L.; Kolarcik, P.; Jarcuska, P.; Pella, D.; Halánová, M.; HepaMeta Team. Socioeconomic characteristics of the population living in Roma settlements and their association with health and health-related behaviour. Cent. Eur. J. Public Health 2014, 22, S57-S64. [CrossRef] 